\title{
Book Reviewing Old Beginnings: Marjorie Watts' P.E.N. The Early Years 1921-1926
}

\author{
DAN HORAT,IU POPESCU \\ Affiliation: Partium Christian University \\ Department of Languages and Literatures, Oradea, Romania \\ Email:dhpopescu@yahoo.com
}

\begin{abstract}
This review of a 1971 book is meant to invite readers to reflect on the role P.E.N. International-a worldwide association of writers, founded in London in 1921 to promote literature and intellectual co-operation among writers-might have given the increasing challenges in our contemporary society. Describing the beginnings of the organization, the book marked P.E.N.'s Golden Jubilee. Therefore, I felt it appropriate to discuss some of the issues it addressed-that is, socializing vs. political activism-as this year, P.E.N. International turned 100.
\end{abstract}

Keywords: writers' organizations, centenary, political activism, socializing, nostalgia

For those interested in what P.E.N is nowadays, thoroughly assess its activity, the internet can provide a swift and complex answer. The P.E.N. site has as its headings "Who we are," "Celebrating literature," "Defending free expression," "Protecting writers at risk," "Supporting writers in exile," "Promoting linguistic rights" and "PEN Centres globally." Apparently (or is it obviously?), it is about writers from all over the world and also about their fight for human rights in the twenty-first century.

In the second spring of the COVID-19 pandemic, having researched the history of the Romanian P.E.N. Club for half a decade already and anticipating the intense exchange of information in the centenary year, I decided to order a copy of a book I had been looking for some while. Amazon fulfilled my desire and the booklet-indeed, as it was a 37-page volume-arrived in a couple of weeks. Authored by Marjorie Watts, née Scott, P.E.N. The Early Years 1921-1926 was published in 1971, marking the half a century existence of the organization.

Marjorie Watts' small book aimed at setting "down the facts concerning the Foundation of the P.E.N. Club" and at giving its "present and future members a picture of her [mother] as Founder" (1971). During World War I Catherine Dawson Scott had set up Women's 
Defence Relief Corps, an organization for women disposed to undertake "civil or semimilitary work which would enable more men to enlist" (Watts, 1971, p. 5). When other similar organizations entered the public space, she started to consider diversifying and expanding or, to quote her daughter, she began "to think internationally" (1971, p. 5). Diversifying meant switching back to her real interest, the literary world, and what she had in mind was to create a social space for writers to meet, especially for the young and aspiring. That was how in the spring of 1917, the To-Morrow Club was founded. It followed the pattern already established by other clubs, so typically British, with members meeting once a week "in a large, low-ceilinged room in Long Acre" (Watts, 1971, p. 6). Marjorie Watts draws an affectionate portrait of her mother, who "undertook to find a subject, speaker and chairman" for each of the sessions, a task that she gracefully accomplished due to "her ability to persuade many distinguished writers" (1971, p. 6).

Despite its reduced dimension, the book is rich in sources of all kinds, as Marjorie Watts meant to underline the most significant items that would capture the spirit of the age. She resorted to her personal recollections-"My mother wrote long, chatty letters to me every week" (Watts, 1971, 11)-and to other people's memories \& testimonies, letters, diary entries, official documents, and so forth. In fact, the voice of Marjorie's mother "was influential in the adjusting of reputations on that literary bourse (of London)," in other words, the establishment had to pay attention to what was going on in the literary market of the emerging consumerist society (1971, p. 9).

No wonder that when the idea of P.E.N. Club occurred to Mrs. Dawson Scott, in the summer of 1921, among its first supporters was an American publisher. "If I get started here, will get going to America," she was writing to her daughter (1971, p. 12). She was pointing to a reality that used to work predominantly a single way for more than a century. American authors were always looking at Europe as the epitome of culture. With a certain flair for business, Catherine Dawson Scott had realized that if Britain were to retain its supremacy, then she should look for solid American partners - "If it is to be international, it must have an American who knows who's who on that side of the water" (Watts, 1971, p. 12).

Such amplitude requires rules, but before establishing them, it is the guiding principles that readers should notice. Gender equality was at the front-"This must be a real manand-woman club, not me doing everything," she was writing to Marjorie (1971, p. 12), as she had at times felt overwhelmed at the To-Morrow Club. Among those who responded enthusiastically to her call and the list of proposals was John Galsworthy. His portrait in the book matches the magnitude of Mrs. Scott's. They had known each other since the founding of the To-Morrow Club, as he had been among the early speakers. 
They were very different in character and yet complementary to each other-she gay, enthusiastic and forthright, unconventional and wayward; Galsworthy shy, quiet and unhurried, wise and deliberate, unswayed by emotions, though often moved. But they had certain fundamentals in common-a deep belief in internationalism, a dislike of grandeur and show, snobbishness and racial prejudice-and they both loved the under-dog. (Watts, 1971, p. 16)

One should not read "internationalism" in the above quote as having any leftist connotation. On the contrary, British and American writers were paying close attention to the emergent threat of communism, as seen in an episode detailed by Marjorie Watts. Edith Wharton, the woman novelist approached to be appointed an Honorary Member for America, turned down the invitation as she considered inappropriate the selection for the French Centre-that is Romain Rolland and Anatole France, both outspoken supporters of the 1917 Russian Revolution-and she was not happy to see her name on the same list.

Not surprisingly, power games were fast developing. The French Centre had been the first established, and some of its members might not have been very happy with London as the literary capital of Europe \& the world. At a P.E.N. Congress in Paris, Catherine Dawson Scott found out that they intended "to recommend that the International Council should have its headquarters" in the capital of France (Watts, 1971, p. 29). Galsworthy was summoned by Marjorie and he tackled the issue and had the idea dropped.

Across the Atlantic, the power games involved writers from New York and Chicago when it came to the establishment, in 1922, of the American Centre. A trained and skillful lawyer, a master in the art of negotiation, Galsworthy reflected on the issue and wrote to Marjorie that they, the P.E.N. Centre in London, would "have to adopt a policy of recognizing New York as the American Centre, with any branches that they may advise us to recognise" (Watts, 1971, p. 22).

In a letter from 1924 to Catherine Dawson Scott, while pondering over the political options of one of their acquaintances, Galsworthy wrote a sentence, as retained by Marjorie, which makes us wonder how things evolved in time in what concerns P.E.N.'s activity and types of engagement-"It all comes back to the question whether we can be in the least sure that we shall be dealing with literary men or disguised politicians" (1971, p. 28).

In Catherine Dawson Scott's view, in the beginning P.E.N. was P.P.E.N. and stood for "Poet, Playwright, Editor, Novelist" (Watts, 1971, p. 11) and the rules regarding qualifications for membership indicated a book of verse/a play/a novel or "the editorship, past or present, of a well-known paper or magazine" (p. 14). Eventually, editors were left out, 
and only Poets/Playwrights, Essayists and Novelists remained to comply with the rules stipulating that, for instance, dinners should be held on Tuesday with booking "before 12 noon the same day" (p. 14). Members were allowed to bring visitors, either writers or "persons of distinction," so the socializing component was carefully observed (p. 14).

The epitome of all these was the annual banquet, and Marjorie Watts remembers the last one she was directly involved, in November 1926. The banquet took place at the Hyde Park Hotel under predominantly Central-European auspices, as "the distinguished patrons were Their Excellencies, the Austrian, Hungarian, Polish, Roumanian and Swedish Ministers" (Watts, 1971, p. 35).

My internet led me to an article describing the event. Its author underlines the contrast between the contemporary P.E.N., which has "an explicitly political identity," and the logic behind its formation "as a social rather than political organization" (Nunes, 2016). The Book Ball planning committee member John Drinkwater is quoted, and the author believes that club, and not P.E.N., is the operative word here "with all of its connotations of social glamour and elite exclusivity" (Nunes, 2016).

Where does P.E.N. stand nowadays is a tricky question to raise, and one could not but give it a deep nostalgic reflection and consider Europe's Golden Age in the Roaring Twenties when observing, in the 1926 ball programme,

the decadent menu featuring such delicacies as SOUPER Consommé Double en Tasse/ Paillets au Parmesan/ Suprême de Sole Claudinete/ Poularde poêle mascotte/ Pomme Mignon/ Salade Trianon/ Petit pois bonne femme/ Soufflé glacé Tosca/ Friandises; BUFFET Petit Pains Rossini/ Boucheé Montglas. (Nunes, 2016)

So, "Où sont les neiges d'antan?" one might humbly (or maliciously?) ask.

\section{References}

Nunes, C. (2016). Book Balls, fox-trots, and boeuf bordelaise: The early history of international P.E.N. Ransom Center Magazine March 17, 2016. https://sites.utexas. edu/ransomcentermagazine/2016/03/17/book-balls-fox-trots-and-boeuf-bordelaise-the-early-history-of-international-p-e-n/

Watts, M. (1971). P.E.N. The Early Years 1921-1926. Archive Press. 